\title{
The Role of Religiosity on Halal Product Purchasing Decision Case Study: Wardah Cosmetics
}

\section{Farah Amalia}

Faculty of Islamic Economics and Business, Islamic State University of Walisongo Semarang, Indonesia

\section{A R T I C L E I N F O}

Article history:

Received 07 Desember 2019

Received in revised form 16 Januari 2019

Accepted 16 Januari 2019

Keywords:

Halal Cosmetics, Religiosity, Decision

Making in Product Purchasing

\begin{abstract}
A B S T R A C T
The purpose of this study is to examine the effect of religiosity in making decisions about purchasing halal cosmetic products. This study uses regression analysis using purposive sampling technique that is sampling in the form of characteristics that have been determined by researchers. The results showed that religiosity affects Muslim consumers in the decision making to purchase halal cosmetic products. Practical implications for the cosmetics industry is to focus on product development based on the concept of halal in order to participate in the global market competition. The importance of considering consumer religiosity in order to gain recognition from national and international markets so that the image of the cosmetics industry has a place in the hearts of consumers.
\end{abstract}

\section{A B S T R A K}

Tujuan penelitian ini menguji pengaruh religiusitas dalam pengambilan keputusan pembelian produk kosmetik halal. Penelitian ini menggunakan analisis regresi dengan pengambilan sampel menggunakan teknik purposive sampling yaitu pengambilan sampel berupa ciri- ciri atau karakteristik yang telah ditentukan oleh peneliti. Hasil penelitian menunjukkan bahwa religiusitas mempengaruhi konsumen muslim dalam pengambilan keputusan pembelian produk kosmetik halal. Implikasi praktis bagi industri kosmetik agar memfokuskan pengembangan produknya berdasarkan konsep halal guna turut serta berkompetisi di pasar global. Pentingnya mempertimbangkan religiusitas konsumen guna meraih pengakuan dari pasar nasional dan internasional sehingga citra industri kosmetik mendapat tempat di hati konsumen.

* Corresponding author. email: farhasjmi@walisongo.ac.id http://dx.doi.org/10.21580/jdmhi.2019.1.1.4774 


\section{Introduction}

Indonesia is the country with the largest muslim population in the world (www.globalreligiousfutures.org). The Ministry of National Development Planning notes that the population of Indonesia in 2018 reached 265,000,000 lives. 87.2\% of the total population is Muslim and the rest are Christian, Catholic, Hindu, Buddhist and Confucian (www.indonesia.go.id). Islam is a religion that has comprehensive regulations and doctrines, it contained all aspects of the life of every human being. All aspects of life are regulated in the Qur'an and are used as guidelines in all human activities. One aspect that is regulated inside Al-Quran is the concept of halal. Allah Almighty says in Surah Al-Maidah verses 87-88 "And eat food that is lawful again good than what Allah has blessed you, and fear Allah you believe in Him." In the Al-Baqarah verse 172-173 explained that "Verily Allah only forbids you carcasses, blood, pork, and animals which (when slaughtered) are called (names) besides Allah. but whoever is in a state forced to (eat it) while He does not want it and does not (also) exceed the limits, then there is no sin for him. Truly Allah is Forgiving, Most Merciful. "These two verses clearly explain the necessity of a Muslim to consume halal products.

The halal paradigm is something that is primary and important in raising awareness among Muslims and is a dynamic and cyclical process as a final decision (Wilson. J \& Liu. J, 2011). Decision in the context of research is the decision to purchase a product. Kotler and Armstrong (2003: 227) said that purchasing decisions are a stage in the purchasing decision process where consumers really buy. Decision making is also defined as an individual activity that is directly involved in obtaining and using the goods offered. High consumer purchasing decisions can result in high product sales volumes.

The development of Indonesia's cosmetics industry has now grown so rapidly. Based on a survey conducted by Bizteka-CCI in 2015 the national cosmetics market is estimated to grow $8.3 \%$ with a value reaching $\mathrm{Rp} .13 .9$ trillion, an increase compared to the previous year (2014) of Rp. 12.8 trillion. One of the successful local cosmetics brands to dominate the market is Wardah. Wardah is a pioneer of cosmetic products that prioritizes halal principles and has obtained halal certificates from MUI. The ingredients used in the composition of Wardah cosmetics are quality ingredients and halal proven. The halal ingredients can be traced to the absence of materials commonly used in cosmetics which are the critical points of halalness such as fat, collagen, elastin, placenta extract, vitamin stabilizers, alpha hydroxyl acids, and hormones. These ingredients are very vulnerable because they may come from forbidden animal fat (tikamustofa.com, 2018). Wardah gets the 2018 Top Brand Index as follows,

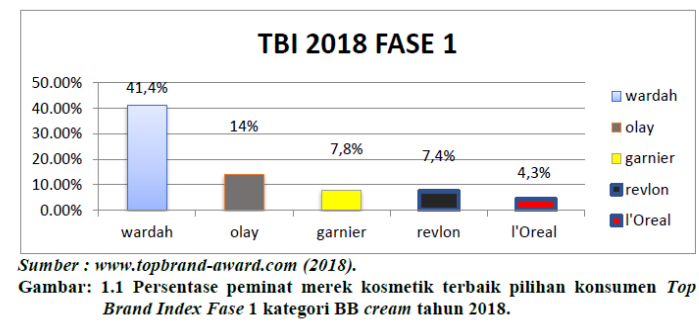

The graph explicitly interprets the high sales volume of wardah products compared to other cosmetic brands. The high volume of wardah product sales is thought to be caused by halal labels that are listed on all of its 
products. In the process of purchasing decisions, consumers will look for product information in terms of price, usability, packaging and halal labels. With the inclusion of halal labels, consumers feel more secure in consuming and using the product. Muslim consumers who are committed in religion will certainly choose halal products related to the regulation and doctrines of Islamic religion they profess.

\section{Literature Review}

\section{Religiosity}

Religious Commitment (Religiosity) refers to the level one has of the values of religiosity, beliefs and religious practices in daily life Worthington, et al (2003: 85). According to Grace in (Astogini et al, 2011) Religiosity is a form of feeling a person towards the religion they profess, the feeling is related to a belief, symbol, value and activity which is the encouragement of religious power. Religiosity is defined as an individual's commitment to religion and the teachings contained in it, including commitment based on religion towards its attitudes and behavior (Johnson, B.R et.al, 2001).

\section{Purchasing Decision}

Purchasing decision is an act of consumer behavior towards determining the purchase decision to buy a product or not and based on the intention to make a purchase. Purchasing decisions made by a consumer before they make purchasing activity and have a continuation after making a purchase. (Subianto, 2007). According to Amirullah in Narjono (2012: 8) the purchasing decision is a process where consumers make choices and choose alternatives needed based on certain considerations.

The Role of Religiosity in Making Decisions to Purchase Halal Products Religious aspects in daily life are very important in order to implement religious rules in carrying out an activity both the activity of eating, drinking, making a purchasing decision. The consumption behavior of a Muslim is based on the assumptions put forward by Monzer Khaf, including:

1. Islam is a religion that is applied in the community

2. Zakat is obligatory

3. There is no usury in the community

4. The Mudharabah Principle is applied in business

5. Consumers behave rationally by trying to optimize satisfaction. (Sarwono, 2009)

In Islamic view, consumer behavior does not only meets physical needs but also by meet spiritual needs. In other words, consumption behavior carried out by Muslim consumers is a part of worship that is a means to obtain merit so that the model of Muslim consumer behavior must be in accordance with Islamic rules and doctrines. This view should make a Muslim consumer always choose products that are clearly halal and be careful of products that are not clearly halal yet. Religious consumers take advantage of product information through halal food labels and avoid uncertainty or risk. The result of Imamuddin's research (2017) states that religiosity influences a person in purchasing Instant Noodle. In line with Mukhtar, A \& Butt, M's research in 2012 which concluded that religiosity in general and Islam in particular, became an integral part of culture and influenced the interest of 
researchers to explore the role of religiosity in purchasing decisions.

Therefore the hypothesis put forward is as follows:

H1: Religiosity influences consumers in making halal comestible purchasing decisions.

\section{Method, Data, and Analysis}

\section{Research Method}

The method used in this research is quantitative descriptive. Quantitative descriptive research is research using data collected and expressed in the form of numbers and in the form of data used as supporters (Sugiyono, 2011). In terms of place, this type of research is the type of field research (field research), which is by conducting research in the field in order to obtain data / various information directly, namely by visiting correspondents or visiting locations that are used as writing objects so that the data needed to support writing can be obtained. Data collection uses a questionnaire with measurement instruments which are a series of statements formally compiled to obtain information from respondents (Malhotra, Naresh K. 2010). The population used in this research is consumers who have bought Wardah products. Sampling uses a purposive sampling technique with certain criteria. The criteria used are Wardah consumers who are adults at least seventeen years old and are Muslim. Age criteria are determined at least seventeen years on the grounds that at that age a person has been able to make decisions independently regarding what to do and the consequences of his actions. The criteria for Islamic religion are determined in relation to the halal and haram paradigms that are implemented in each individual's religiosity. From a total of 100 questionnaires distributed, there were 77 respondents who met the criteria.

\section{Research model}

This research model was adapted and adopted from the research of Nasution et al 2016 and Mutaalimah 2018,

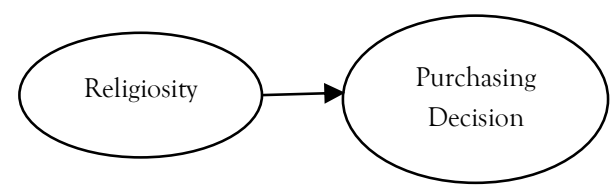

\section{Result and Discussion}

Table 1 Model Summary

\begin{tabular}{|l|c|c|c|c|}
\hline \multicolumn{5}{|c|}{ Model Summary $^{\text {b }}$} \\
\hline Model & $\mathrm{R}$ & $\begin{array}{c}\mathrm{R} \\
\text { Squa } \\
\text { re }\end{array}$ & $\begin{array}{c}\text { Adjusted } \\
\text { R Square }\end{array}$ & $\begin{array}{c}\text { Std. Error } \\
\text { of the } \\
\text { Estimate }\end{array}$ \\
\hline 1 &, $520^{\mathrm{a}}$ &, 270 &, 260 & 1,190 \\
\hline \multicolumn{5}{|l|}{ a.Predictors: (Constant), Religiosity (X) } \\
\hline \multicolumn{4}{|l|}{ b.Dependent Variable: Purchasing Decision (Y) } \\
\hline
\end{tabular}

Table 2 Regression Result

\begin{tabular}{|c|c|c|c|c|c|c|}
\hline \multicolumn{7}{|c|}{ Coefficients } \\
\hline \multirow{2}{*}{\multicolumn{2}{|c|}{ Model }} & \multicolumn{2}{|c|}{$\begin{array}{l}\text { Unstandar } \\
\text { Dized Coeff }\end{array}$} & Standar & \multirow[t]{2}{*}{$\mathrm{t}$} & \multirow[t]{2}{*}{ Sig. } \\
\hline & & B & $\begin{array}{l}\text { Std. } \\
\text { Err }\end{array}$ & Beta & & \\
\hline \multirow[t]{2}{*}{1} & Constant & 3,23 & 2,023 & & 1,597 & ,115 \\
\hline & $\begin{array}{l}\text { Religiu } \\
\text { sitas }\end{array}$ &, 171 & ,033 &, 520 & 5,266 & ,000 \\
\hline
\end{tabular}

Based on the results of the regression table shows that the significance of 0,000 or $<0.05$. 
This figure interprets that there is an influence of religiosity on purchasing decisions. The influence of religiosity on purchasing decisions is unidirectional. The higher the religiosity of a Muslim, the greater the person's chances of making a decision to buy halal products. Based on the table $\mathrm{R}$ square value of 0.270 means that the variable religiosity affects the purchase decision by $27 \%$ and $73 \%$ is explained by other factors outside the variable.

\section{Discussion}

The results of this study are in line with research (Nugroho Anton, P, Hidayat, \& Kusuma, 2017) which says that religiosity has a positive relationship to improving society using Islamic banks. The religiosity of a Muslim can be seen from his daily behavior, including their behavior related to economic activities. A religious person will avoid all of his economic activities that are prohibited then one of the economic activities is to avoid the forbidden activities by using Islamic banking services. Because Religiosity here is part of the behavior, the level of religion for the behavior of Islamic bank customers is increasing in using the services and products of Islamic banks.

Islam has rules about the behavior of its people in buying and consuming various products including food and drinks. The religiosity of Muslim consumers positively influences cosmetics purchasing decision making. Muslim consumers before making a purchase decision will first seek information related to the halal nature of the cosmetics used. This shows the religious value that is embedded and is taken into consideration when making decisions. The results of this study are consistent with the literature which states that individuals who have high religiosity tend to behave in a relatively more disciplined, mature and responsible manner. Religious consumers make good use of product information through halal food labels and avoid uncertainty or risk.

\section{Conclusion}

Based on the results dan discussion, it can be conclused that religiosity significantly impact consumer purchasing decision to buy halal products. The higher the religiosity of a Muslim, the greater the person's chances of making a decision to buy halal products. In this case, the halal product determined is cosmetics, wardah brand.

\section{Recommendation}

Based on the results, discussion and conclusion, the author recommends some other variables to be added on next research to increase $\mathrm{R}$ square value and strengthen the research result. Furthermore, the author suggests another halal product categories such as food and beverages, toiletries etc so the research result can be relevant to daily life.

\section{References}

Astogini, D., Wahyudin, \& Wulandari, S. Z. (2011). Aspek Religiusitas Dalam keputusan Pembelian Produk Halal (Studi tentang labelisasi halal pada produk makanan dan minuman kemasan). Jurnal JEBA, 13(1) 
Wilson. J.A.J \& Liu. J, 2011, “The Challenges of Islamic branding: navigating emotions and halal”, Journal of Islamic Marketing, Vol.2 No.1

Johnson, B.R et.al, 2001, Does adolescent religious commitment matter? A reexamination of the effects of religiosity on delinquency, Journal of Research in Crime and Delinquency

Imamuddin, M. (2017). Pengaruh Label Halal Dan Religiusitas Terhadap Keputusan Pembelian Mie Instan Mahasiswa IAIN Bkittinggi T.A 2016/2017. Journal of Economic Studies, 1(1),

Mukhtar, A \& Butt, M. M, 2012, "Intention to choose Halal Products: the role of religiosity", Journal of Islamic Marketing, Vol.3 No.2

Nugroho Anton, P, Hidayat, A., \& Kusuma, H. (2017). The Influence Of Religiosity and Self-Efficacy On The Saving Behavior Of The Islamic Banks. Jurnal Banks and Bank Systems, 12(3)

Malhotra, Naresh K. 2010, Marketing Research: An Applied Orientation 6th edition, New Jersey:Pearson

Sugiyono. (2011). Metode Penelitian Kuantitatif, Kualitatif, dan REDD. Bandung: CV.Afabeta

\section{Website:}

www.globalreligiousfutures.org

www.indonesia.go.id

www.detik.com 
http://journal.walisongo.ac.id/index.php/JDMHI/index http://dx.doi.org/10.21580/jdmhi.2019.1.1.4774 